\title{
Pathobiology of cardiac dyssynchrony and resynchronization therapy
}

Citation for published version (APA):

Chau Nguyen, U., Verzaal, N. J., van Nieuwenhoven, F. A., Vernooy, K., \& Prinzen, F. (2018).

Pathobiology of cardiac dyssynchrony and resynchronization therapy. EP Europace, 20(12), 1898-1909. https://doi.org/10.1093/europace/euy035

Document status and date:

Published: 01/12/2018

DOI:

10.1093/europace/euy035

Document Version:

Publisher's PDF, also known as Version of record

Document license:

Taverne

Please check the document version of this publication:

- A submitted manuscript is the version of the article upon submission and before peer-review. There can be important differences between the submitted version and the official published version of record.

People interested in the research are advised to contact the author for the final version of the publication, or visit the DOI to the publisher's website.

- The final author version and the galley proof are versions of the publication after peer review.

- The final published version features the final layout of the paper including the volume, issue and page numbers.

Link to publication

\footnotetext{
General rights rights.

- You may freely distribute the URL identifying the publication in the public portal. please follow below link for the End User Agreement:

www.umlib.nl/taverne-license

Take down policy

If you believe that this document breaches copyright please contact us at:

repository@maastrichtuniversity.nl

providing details and we will investigate your claim.
}

Copyright and moral rights for the publications made accessible in the public portal are retained by the authors and/or other copyright owners and it is a condition of accessing publications that users recognise and abide by the legal requirements associated with these

- Users may download and print one copy of any publication from the public portal for the purpose of private study or research.

- You may not further distribute the material or use it for any profit-making activity or commercial gain

If the publication is distributed under the terms of Article $25 \mathrm{fa}$ of the Dutch Copyright Act, indicated by the "Taverne" license above, 


\title{
Pathobiology of cardiac dyssynchrony and resynchronization therapy
}

\author{
Uyên Châu Nguyên ${ }^{1,2 \dagger}$, Nienke J. Verzaal ${ }^{1 \dagger}$, Frans A. van Nieuwenhoven ${ }^{1}$, \\ Kevin Vernooy ${ }^{2}$, and Frits W. Prinzen ${ }^{1 *}$
}

\begin{abstract}
${ }^{1}$ Department of Physiology, Cardiovascular Research Institute Maastricht, Universiteitssingel 50, 6229 ER Maastricht, The Netherlands; and ${ }^{2}$ Department of Cardiology, Cardiovascular Research Institute Maastricht, Universiteitssingel 50, 6229 ER Maastricht, The Netherlands
\end{abstract}

Received 2 January 2018; editorial decision 11 February 2018; accepted 16 February 2018; online publish-ahead-of-print 15 May 2018

Synchronous ventricular electrical activation is a prerequisite for adequate left ventricular (LV) systolic function. Conduction abnormalities such as left bundle branch block, and ventricular pacing lead to a dyssynchronous electrical activation sequence, which may have deleterious consequences. The present review attempts to connect the various processes involved in the development of 'dyssynchronopathy', and its correction by cardiac resynchronization therapy (CRT). Abnormal electrical impulse conduction leads to abnormal contraction, characterized by regional differences in timing as well as shortening patterns and amount of external work performed. Early activated regions may show 'wasted work', which leads to inefficient action of the entire left ventricle. Moreover, both the development of heart failure (HF) in general and the regional differences in mechanical load lead to structural, electrical, and contractile remodelling processes. These have been demonstrated at the level of the myocardium (asymmetric hypertrophy, fibrosis, prolongation of activation and reduction in repolarization forces, decrease in LV ejection fraction), cell (gap junctional remodelling, derangement of the T-tubular structure), and molecule (under or overexpression of ion channels and contractile proteins subtypes and abnormal calcium handling). The myocardial adaptations to dyssynchrony are 'maladaptive'. This also explains why CRT, unlike most pharmacological treatments, continues to increase its therapeutic effect over time. Finally, better understanding of all processes involved in dyssynchrony and CRT may also lead to new pharmacological agents for treating HF and to novel pacing strategies.

\section{Keywords Dyssynchrony $\bullet$ Left bundle branch block $\bullet$ Heart failure $\bullet$ Cardiac resynchronization therapy}

- Remodelling - Pathophysiology

\section{Introduction}

Proper cardiac pump function is dependent on fairly synchronous and well distributed electrical activation. The intraventricular rapid conduction system plays a key role in this respect. The importance of this synchronous activation is illustrated by the deviations in structure and function that occur when impulse conduction becomes abnormally slow, as is the case during ventricular pacing and left bundle branch block (LBBB). Slow impulse conduction leads to large time differences in electrical activation and contraction within a ventricle and between the ventricles (intra- and interventricular dyssynchrony, respectively). The combination of all detrimental changes leading to dyssynchrony-induced cardiomyopathy can be termed 'dyssynchronopathy', a disease that can be treated by cardiac resynchronization therapy (CRT). The present overview aims to review and discuss current knowledge on the pathobiology of dyssynchrony and CRT, i.e. the causes and consequences of dyssynchrony and resynchronization for structural and functional processes in the myocardium.

\section{Electrical aspects}

\section{The pathobiology of conduction abnormalities and electrical dyssynchrony}

Synchronous ventricular electrical activation is a prerequisite for adequate left ventricular (LV) function. In the healthy heart this is achieved by propagation of electrical impulses from the atrioventricular (AV) node through the fast-conducting His-Purkinje system. An additional role may be played by fast conducting endocardial fibres, which conduction velocity is in between that of working

\footnotetext{
* Corresponding author. Tel: +31 4338 81080/81200; fax: +31 43 3884166. E-mail address: frits.prinzen@maastrichtuniversity.nl

${ }^{\dagger}$ Equal contribution.

Published on behalf of the European Society of Cardiology. All rights reserved. @ The Author(s) 2018. For permissions, please email: journals.permissions@oup.com.
} 
myocardium and Purkinje fibres. ${ }^{1}$ Of note, functionality of such fibres has only been demonstrated in the dog heart, the conduction system of which seems to be closest to the human heart of all non-primate mammals. 'True' Purkinje fibres are characterized by a larger size ${ }^{2}$ and by overexpression of connexin $43(\mathrm{C} \times 43)^{3}$ compared with endocardial fibres. In relatively simple histological images, the subendocardial fibres in the dog heart appear uniformly oriented but otherwise similar to working myocardium. ${ }^{1}$ Such fibres have not been identified in the human heart, but high resolution micro computed tomography (CT) images show dense networks of Purkinje-like fibres, which may be comparable to the fast conducting endocardial fibres in the dog heart. In the dog heart several studies showed fast impulse conduction along the LV endocardium ${ }^{4,5}$ apparently explaining the benefit of endocardial CRT., ${ }^{4,6,7}$ Although the existence of fast-conducting subendocardial fibres in the human heart is not clear, clinical studies support the evidence that endocardial CRT is at least as beneficial as epicardial CRT. ${ }^{8}$

While the ventricular endocardium is normally electrically activated within $\sim 20 \mathrm{~ms}$, the remaining transmural propagation from endocardium to epicardium requires another $\sim 50 \mathrm{~ms}{ }^{9}$ The Purkinje system may be damaged or bypassed during conduction abnormalities such as LBBB and ventricular pacing. Under these conditions, conduction propagates primarily through working myocardium in which the conduction velocity is almost four times slower compared with the specialized His-Purkinje system. ${ }^{9}$ Additionally, the wavefront of activation changes. Propagation perpendicular to the fibre orientation, is half of that of propagation parallel to the fibres, ${ }^{10}$ contributing to the prolongation of total ventricular activation.

While the cause of abnormal conduction during ventricular pacing is obvious, this is much less the case during bundle branch block. Especially during LBBB, the conduction block may occur at any level in the His-Purkinje system. The wide variation in left bundle branch anatomies further complicates the diagnosis of LBBB. ${ }^{11}$ Left bundle branch block may develop suddenly when its primary blood supply is obstructed or under iatrogenic circumstances, for instance after aortic valve replacement. In the latter case, the block is obviously proximal in the left bundle branch. However, more often, LBBB is a result of slow degeneration of the conduction system due to chronic conditions affecting the myocardium. ${ }^{12}$

There is interesting and growing evidence that, in the latter case, a considerable part of LBBB patients has a proximal block. This evidence comes from the fact that His-bundle pacing creates significant narrowing of the QRS complex in many patients with LBBB. Because this effect can only be explained if pacing occurred distal to the block, this LBBB should be located very proximal in the His bundle or even in the lower part of the AV node. Forty-year old studies already pointed this out, ${ }^{13,14}$ and results were explained by the theory of longitudinal dissociation of the His bundle. This theory assumes that the conducting fibres to the right and left bundle branch are histologically isolated inside the trunk. Injuring the trunk may lead to a complete AV-block or a bundle branch block. ${ }^{15}$ Stimulation of the fibres distal to the bundle branch block can normalize the QRS complex in case of pure His bundle capture and absence of pre-excitation of adjacent myocardium. More recent studies demonstrating ventricular resynchronization through His bundle pacing in CRT candidates reinforced this idea. ${ }^{16}$

\section{Electro-anatomic insights in the pathobiology of electrical dyssynchrony}

After the first crude mapping studies in LBBB and right ventricular (RV)-paced patients by Vassallo et al. ${ }^{17}$ in the 1970 s, detailed mapping studies were performed by Auricchio et al. ${ }^{18,19}$ These studies showed that LBBB was characterized by a slow impulse conduction originating from the RV free wall gradually propagating to the LV lateral wall. ${ }^{19}$ Interestingly, a large variation in trans-septal conduction time (TST) was present in patients referred for CRT. While a few patients almost had simultaneous activation at the right and left ventricle side of the septum (TST near 0), most of the patients with LBBB showed TSTs of $>30 \mathrm{~ms}$, even up to $80 \mathrm{~ms}^{20}$ Long TSTs were also found in canine LBBB hearts, especially in canines with LBBB and tachypacinginduced heart failure (HF). ${ }^{21}$ Slow trans-septal conduction is also evident from epicardial contact maps in ventricular paced canine hearts ${ }^{7}$ and from non-invasive ECG imaging (ECGI) maps in LBBB patients (Figure 1). ${ }^{22}$ The slow conduction across the septum may be explained by its transverse conduction perpendicular to the fibre orientation. However, this is also the case in conduction from endocardium to epicardium of the LV free wall (LVFW), and this conduction is still faster than across the septum. ${ }^{10}$ Apparently, the septum has specific structural abnormalities that slow down conduction, especially after remodelling due to HF. The slow septal conduction reflects an electrical separation between activation of the right and left ventricle (RV and LV), which is proposedly responsible for QRS notching on the electrocardiogram (ECG) characteristic for LBBB. ${ }^{23}$

\section{Non-invasive assessment of electrical dyssynchrony}

Much information about ventricular conduction abnormalities has been obtained using the 12-lead ECG. QRS duration $\geq 150 \mathrm{~ms}$ and a LBBB morphology on the ECG indicate a class $1 \mathrm{~A}$ recommendation for CRT implantation. ${ }^{24}$ However, QRS duration cannot distinguish between right or left sided conduction abnormalities and between inter- and intraventricular dyssynchrony. While QRS morphology provides more information, it is prone to subjective interpretation and there are multiple definitions for specific conduction disturbances such as LBBB. For example, in a small retrospective study of different $\mathrm{LBBB}$ criteria in patients receiving CRT, a 23\% disagreement in LBBB classification was found between the European and American guidelines. $^{25}$

During recent years, multiple non-invasive techniques have been developed that allow more precise analysis of electrical dyssynchrony by incorporation of spatial or temporal information. First of all, there are techniques closely related to the conventional 12-lead ECG, such as vectorcardiography and ultra-high frequency ECG that can be easily implemented in clinical practice. ${ }^{26,27}$ A more complicated technology, ECGI, reconstructs the electro-anatomic activation of the epicardium based on body surface potential measurements using $\sim 200$ electrodes around the chest and a patient-specific heart-torso geometry. ${ }^{28}$ Electrocardiogram imaging allows assessment of both inter- and intraventricular dyssynchrony. ${ }^{22}$ Interestingly, it was shown that a parameter describing interventricular dyssynchrony correlates better with CRT response than parameters of intraventricular dyssynchrony; an observation that was subsequently supported by computer simulations. ${ }^{22,29}$ 


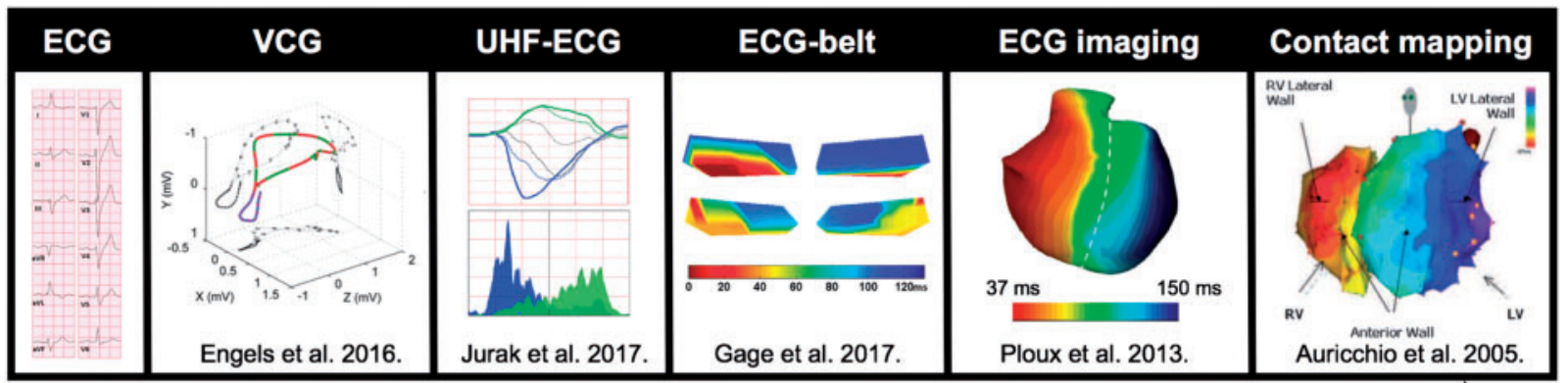

Non-invasive

Invasive

Figure I Overview of electrical dyssynchrony metric approaches. In the ECG imaging and contact mapping panels colour differences within the ventricles represent intraventricular dyssynchrony, whereas the mean difference in colour between the ventricles reflects interventricular dyssynchrony. ECG, electrocardiogram; VCG, vectorcardiography; UHF, ultra-high frequency.

An intermediate approach between the conventional 12-lead ECG and the extensive ECGI is the ECG-belt, where 53 chest electrodes are used. The standard deviation of all ECG-belt derived activation times (SDAT) has been proposed as a novel electrical dyssynchrony metric reflecting electrical heterogeneity. In 66 CRT recipients SDAT, but not QRS duration or morphology, was associated with LV end-systolic reduction and increase of LV function upon starting CRT. ${ }^{30}$ An overview of the aforementioned electrical dyssynchrony assessment techniques is provided in Figure 1.

\section{Mechanics of the dyssynchronous ventricle}

A close relationship exists between excitation and contraction in both the normal ${ }^{31,32}$ and failing heart. ${ }^{33,34}$ The latter was most clearly demonstrated by the use of 3D electromechanical mapping, which allows measuring strains and electrical activation at exactly the same position. $^{33}$

This coupling between excitation and contraction makes it understandable that dyssynchronous electrical activation leads to dyssynchronous ventricular contraction. These contraction abnormalities are complex, as illustrated in Figure 2. Early shortening in earlyactivated regions is followed by a systolic rebound stretch, sometimes showing a bi- or triphasic pattern. In contrast, lateactivated regions are subjected to early-systolic prestretch, followed by augmented systolic shortening that continues into diastole. The most likely physiological explanation for these patterns is that early contraction stretches the not-yet depolarized late-activated regions and that this prestretch activates the local Frank-Starling mechanism, and subsequently, creates a supranormal contraction in late-activated regions. Possibly the best support for this idea are results from simulations in the CircAdapt computer program. In this model, the ventricles are represented by three wall segments (right ventricle, septum, and LVFW), which contain the property of lengthdependent activation. Simply delaying LVFW contraction results in strain patterns in septum and LVFW, which are close to those observed in LBBB patients (Figure 2A). ${ }^{35}$

\section{Assessment of mechanical dyssynchrony}

The analysis of mechanical dyssynchrony has developed rapidly over the last two decades. Initially tissue Doppler imaging was used, ${ }^{38}$ while more recently, techniques to measure strains (length changes) emerged, such as speckle tracking echocardiography, ${ }^{36,39}$ cardiac magnetic resonance (CMR) imaging tagging ${ }^{31,40}$ and more recently feature tracking CMR ${ }^{41}$ and CT-SQUEEZE. ${ }^{42}$ However, still none of the guidelines recommend these techniques for selection of CRT patients. This is explained by the results of randomized clinical studies investigating the use of mechanical dyssynchrony for improving the selection of patients for CRT. Mechanical dyssynchrony had no additional predictive power on top of ECG parameters in cohorts of patients with a wide QRS complex, ${ }^{43,44}$ whereas neutral or even negative results were found when mechanical dyssynchrony was used as the only selection criterion in patients with a narrow QRS complex. ${ }^{45,46}$

In part, these poor results can be explained by limitations of tissue Doppler imaging ${ }^{47}$ and the strong operator dependency of acquisition and analysis of echocardiographic images. On the other hand, considerable differences in time to peak shortening may not only be caused by electrical dyssynchrony but also by regions with low contractility and scar. ${ }^{48}$ Furthermore, peak shortening delay has at best a semiquantitative relation with true dyssynchrony (Figure $2 A$ ). On the other hand, several studies showed the strength of relatively simple measures of dyssynchrony, such as apical rocking and septal flash do improve prediction of CRT response. ${ }^{49-51}$ Further improvements were made by using the analysis of strain patterns, ${ }^{52}$ resulting in parameters such as CURE, ${ }^{53}$ septal systolic rebound stretch, ${ }^{36,54}$ and systolic stretch index. ${ }^{48}$

\section{Functional consequences of mechanical dyssynchrony}

A direct consequence of ventricular dyssynchrony is the reduction in LV function. The gold-standard way to assess LV function is to 


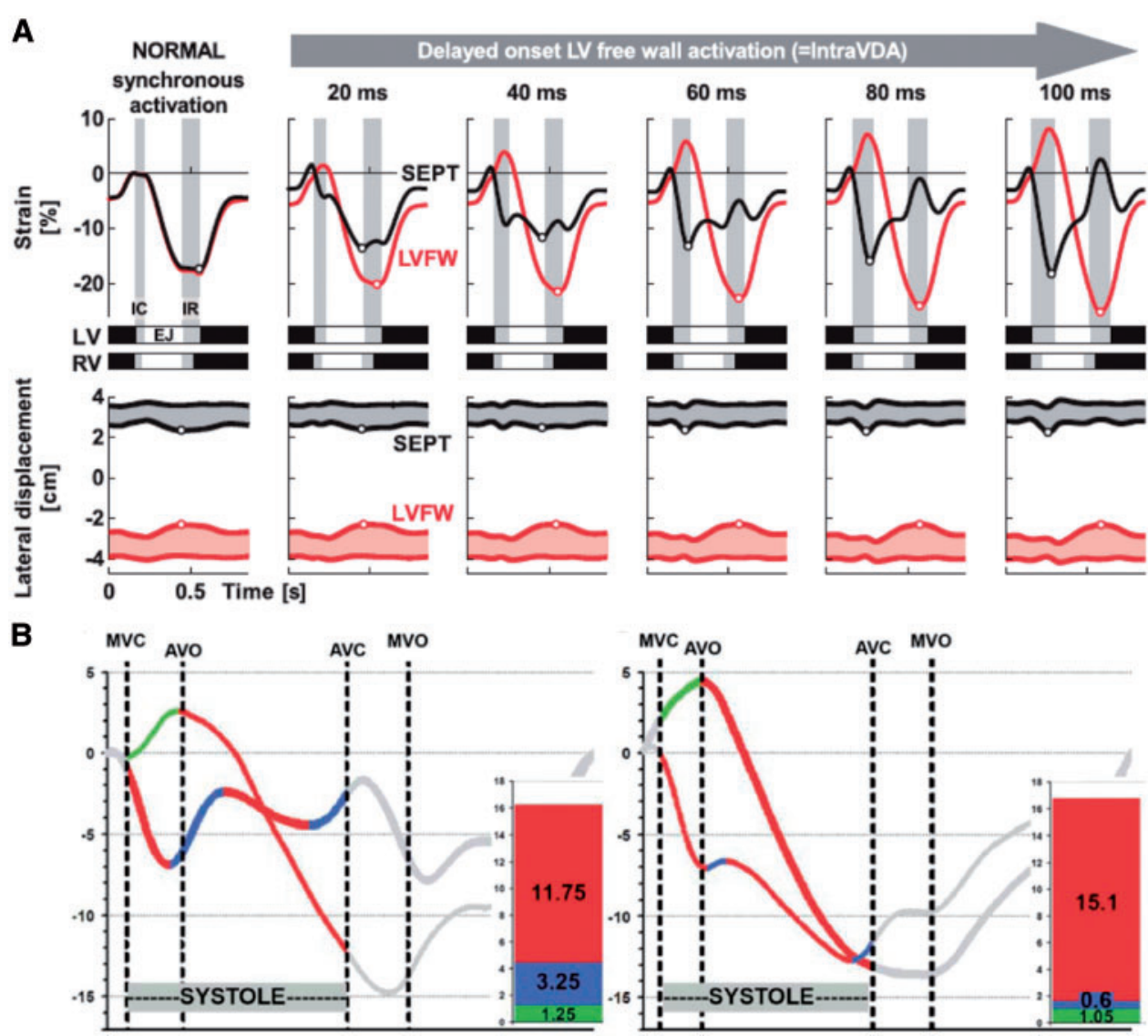

Figure 2 ( $A$ ) Effect of dyssynchronous ventricular activation on mechanical dyssynchrony indices in the CircAdapt model. Computer simulations were performed to predict LV septal and lateral wall strain curves after inducing LVFW delays in increasing severity. (B) Strain patterns measured in a patient before (left) and during CRT (right). Red lines indicate systolic shortening, green early systolic prestretch, and blue septal rebound stretch. The bar graphs indicate that CRT reduces septal rebound stretch and increases systolic shortening of the septum (thick lines) and LVFW (thin lines) combined. Adapted with permission from Leenders et al. ${ }^{37}(A)$ and De Boeck et al. ${ }^{36}(B)$. AVC, aortic valve closing; AVO, aortic valve opening; CRT, cardiac resynchronization therapy; IntraVDA, intraventricular delayed activation; LV, left ventricle; LVFW, left ventricular free wall; MVC, mitral valve closing; MVO, mitral valve opening; RV, right ventricle; SEPT, septal.

determine pressure-volume (PV) loops. Immediately after the onset of dyssynchrony, the PV-loop shows a rightward shift, indicating that the LV needs to operate at a larger volume in order to generate the same pressure; furthermore, stroke volume decreases. ${ }^{55}$ The reverse process has been observed upon starting CRT in patients. ${ }^{56}$ This poorer pump function is largely caused by the reduced systolic shortening in early-activated regions, which is hardly compensated by an increase in shortening in late-activated regions, at least during the ejection phase. As a consequence, in LBBB hearts septal rebound stretch is a good predictor of CRT response. ${ }^{36}$

Such septal stretch during systole implies that this region dissipates energy that was generated in opposing regions. ${ }^{57,58}$ In this respect Russell et al. ${ }^{58,59}$ introduced the term 'wasted work'. Using an elegant method, these investigators were able to show that the ratio of wasted and positive work predicts CRT response. ${ }^{58}$ Importantly, the same research group recently showed that increasing afterload increases the amount of wasted work and disproportionally reduces global longitudinal strain and LV ejection fraction (LVEF). ${ }^{60}$ This finding suggests that the dyssynchronous heart is more sensitive to additional increases in cardiac work load than synchronous hearts and that the afterload should be taken into account when quantifying mechanical dyssynchrony.

The acute haemodynamic benefit of CRT can be understood from its correction of electromechanical dyssynchrony. Certainly in the heart with LBBB, CRT achieves a great deal of normalization of strain patterns and almost vanishing of septal rebound stretch ${ }^{36}$ and wasted work. ${ }^{58}$

A further consequence of the wasted work in the dyssynchronous heart is that the efficiency of conversion of metabolic energy (myocardial $\mathrm{O}_{2}$ consumption) to mechanical energy (stroke work) at the level of the entire left ventricle can be up to $30 \%$ lower during LBBB or RV pacing when compared with normal activation. ${ }^{61}$ Conversely, CRT increases ventricular efficiency, which translates into a lower myocardial perfusion requirement for the same amount of pump work performed ${ }^{62-64}$ and into a larger perfusion reserve. ${ }^{65}$ Because many CRT patients may also have compromised coronary perfusion, CRT may also lower the risk or amount of underperfusion. This all may explain why wasted work ${ }^{66}$ and the work ratio between the septum and LVFW ${ }^{67}$ are good predictors of CRT response. 


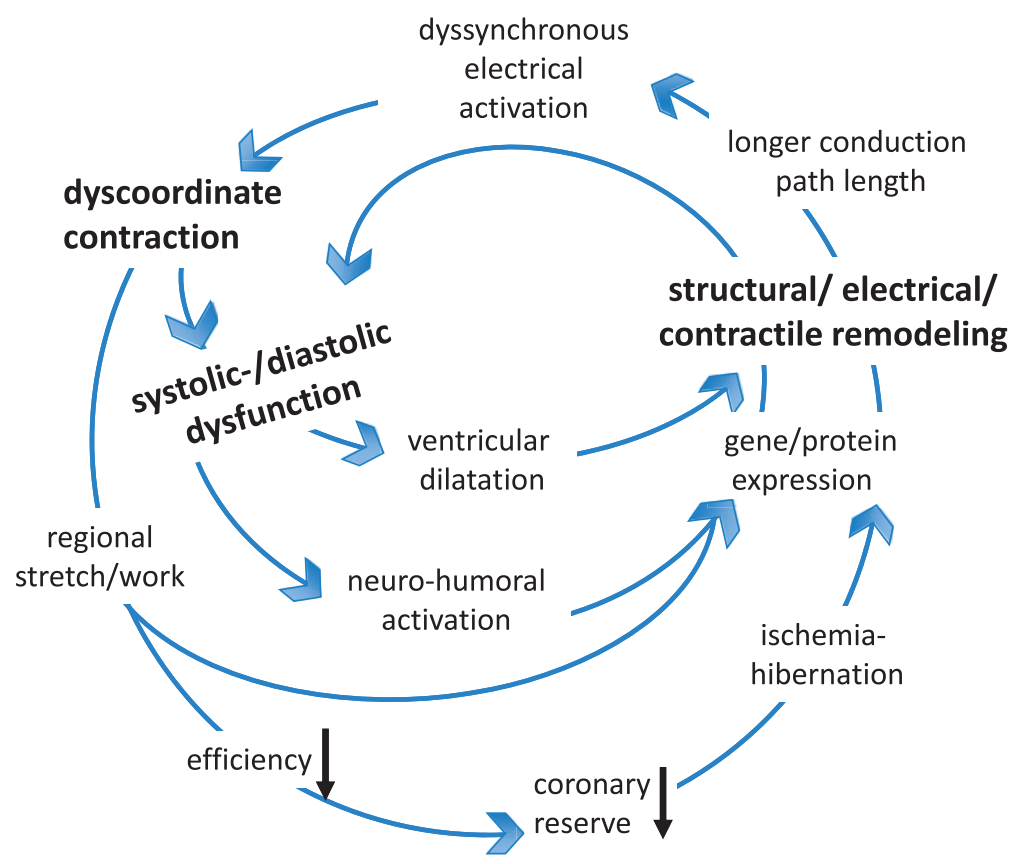

Figure 3 Schematic representation of maladaptive processes following the onset of dyssynchronous activation (see text for details).

A third consequence of dyssynchrony is the considerable redistribution of myocardial work within the ventricles. Because systolic shortening (so shortening against a pressure) in the septum is approximately zero, external work is also zero. In contrast, systolic shortening and external work are supranormal in the LV lateral wall (Figure 2). Accordingly, also myocardial blood flow is redistributed, both in experimental LBBB models ${ }^{68,69}$ and in patients. ${ }^{63}$ The fact that this redistribution is reversed by CRT, concurrent with the homogenization of local strains and work ${ }^{69}$ indicates that workload drives flow and not the other way around. Earlier work of Amitzur supports this view by showing that administration of adenosine in RV paced hearts changes local blood flow but not contraction patterns. ${ }^{70}$

Figure 3 summarizes how the various acute consequences of dyssynchronous electrical activation, mentioned above, lead to worsening cardiac function and ventricular dilatation. In clinical terms, the diminishment of systolic function is evidenced by a lower LVEF and lower strains, worse diastolic function by reduced diastolic filling times and the dilation is shown by a larger LV end-diastolic volume and a rightward short of the PV-loop in conductance catheter measurements. ${ }^{56}$

\section{Remodelling: from myocardium to molecule}

Figure 3 also depicts that 'dyssynchronous HF' leads to unique and extensive gene and protein expression patterns that can be linked to structural as well as electrophysiological and contractile changes. ${ }^{71-73}$ These 'remodelling processes' are driven by neurohumoral factors, like adrenergic stimulation and activation of the renin-angiotensin-aldosterone system (RAAS), and by the mechanical load on the heart itself. ${ }^{74}$ Although the exact mechanisms for transmitting mechanical load to the myocardial cells are not clear, ${ }^{75}$ stretch is a well-known trigger for changing cellular and organ function, both in vitro and in vivo. ${ }^{55,76-78}$ Typically, in LBBB, the early systolic prestretch and augmented external work in late-activated regions seem logical explanations for the frequently more pronounced remodelling processes in these regions.

Because in-depth understanding of (reverse) remodelling processes requires invasive procedures, like biopsies, most knowledge in the field of dyssynchrony and resynchronization is derived from various animal models of dyssynchrony. ${ }^{79}$ The most straightforward way is to induce dyssynchrony by RV pacing or by LBBB, induced using radio frequency ablation while maintaining a normal heart rate. However, since such dyssynchrony reduces pump function but does not lead to HF within a period of half a year, ${ }^{68}$ several groups have added an increase in heart rate, ranging from 120 to 220 b.p.m. for a period of $3-4$ weeks to 24 months. ${ }^{80,81}$ In all these models, resynchronization has been employed using biventricular pacing. Importantly, studies with tachypacing dyssynchronous HF use also tachybiventricular pacing to resynchronize, which will be referred to as tachy-CRT. Tachy-CRT hardly improves functional parameters like LVEF, but reveals many changes at the cellular and molecular level presumably as a consequence of the better co-ordination of contraction. $^{82,83}$

\section{Structural remodelling}

In patients with dyssynchronous HF, CRT induces reverse remodelling with a reduction in LV end-systolic volume (LVESV) ${ }^{84,85}$ and reduced fibrosis. ${ }^{86,87}$ CRT responders (defined by LVESV reduction) 
were also shown to have a decreased LV mass and regional wall thickness, with improved LV geometry, as determined by the sphericity index. ${ }^{88,89} \mathrm{An}$ interesting observation is that polymorphisms in the mineralocorticoid receptor gene proved an important determinant for reverse remodelling in CRT patients. ${ }^{90,91}$ This supports the view that the RAAS is strongly involved in the remodelling process in dyssynchronous failing hearts. These clinical studies suggest that the capability to reverse the remodelling is an important determinant of long-term CRT response. It seems reasonable to suggest that the overall decrease in LV wall mass and the reduced fibrosis upon CRT are mediated by the improved LV systolic function. A reduction in LV cavity volume decreases wall stress and, together with the increased LV function, potentially lowers neurohumoral activation. The reduction in workload in the late-activated LVFW may be responsible for the excess reduction in LVFW mass.

Animal models of LBBB with natural heart rate show ventricular dilatation in combination with asymmetric hypertrophy, the most pronounced hypertrophy occurring at sites of late activation. ${ }^{55,69}$ The presence of this asymmetric hypertrophy (measured both by echocardiography and post-mortem histology ${ }^{55,92}$ ) is accompanied by local molecular changes such as decreased miR133a expression and overexpression of connective tissue growth factor (CTGF) selectively in the LV lateral wall. ${ }^{92}$ These local changes and their reversal upon applying $\mathrm{CRT}^{69,92}$ are a strong indication of the importance of local mechanics for remodelling, because all regions of the dyssynchronous heart are subjected to the same neurohumoral stimulation. While the increase in LV cavity volume after onset of LBBB may directly follow the loss in LV systolic function (Figure 3), further LV dilatation may be mediated by changes in the extracellular matrix (ECM) properties and matrix metalloproteases (MMPs). This fits with the finding of ECM-remodelling and increased MMP activity in the LVFW of RV-paced $\operatorname{dogs}^{93}$ and in dogs with tachypacing-induced dyssynchronous HF. ${ }^{81,94}$ The RV-pacing study also showed ECM accumulation (fibrosis) in the late-activated LVFW. ${ }^{93}$ By contrast, in dogmodels of dyssynchrony without significant cardiac dysfunction (LBBB or LV pacing), myocardial collagen content was not affected, ${ }^{55,92,95}$ although this did occur in a study of tachypacinginduced dyssynchronous HF. ${ }^{81}$ In patients, a modest reduction in fibrosis was observed after CRT, ${ }^{86,87}$ which may be explained by a lower neurohumoral activation. Also, expression of paracrine factors contributing to fibrosis or hypertrophy, including osteopontin, transforming growth factor beta, CTGF, and B-type natriuretic peptide, is increased during dyssynchrony and (partly) normalized by CRT. ${ }^{92,94,96}$

Besides cardiomyocyte hypertrophy and ECM accumulation, apoptosis contributes to the cardiac remodelling process in dyssynchronous HF. An overall increase in various pro-apoptotic factors (such as caspases) has been shown in dyssynchronous HF. ${ }^{97,98}$ This pro-apoptotic state is ameliorated by CRT and the regional variance in the expression of several stress-kinases is reduced. ${ }^{97}$ The proapoptotic factor tumour necrosis factor alpha (TNF $\alpha$ ) is increased in animal models of dyssynchrony ${ }^{97,99}$ and in patients eligible for CRT. ${ }^{87}$ In the animal model, the most pronounced increase in TNF $\alpha$ levels occurs in the LVFW, with tachy-CRT partially normalizing TNFa expression. ${ }^{97}$ In accordance with this, also patients show reduced TNF $\alpha$ levels following CRT. ${ }^{86,87}$ Moreover, DNA-fragmentation, a marker of apoptosis, is increased in dyssynchronous HF and reduced by CRT. ${ }^{86,97,98}$ Interestingly, increased DNA fragmentation occurs in both the septum and the LVFW and tachy-CRT is capable of reducing the occurrence of this process in both locations. ${ }^{97}$

\section{Electrical remodelling}

Electrical remodelling in dyssynchronous and resynchronized hearts may affect both the sequence of depolarization and repolarization.

Changes in the depolarization sequence have been observed from the broadening of the QRS complex during longer lasting dyssynchrony in animal models. ${ }^{55,68}$ Similarly, longer lasting CRT has been reported to decrease QRS duration (both the paced and the non-paced QRS complex) in patients. ${ }^{100}$ Beside changes in the gross anatomy (changes in LV mass and diameter and degree of fibrosis) discussed above, also changes in ion channels may play a role. Figure $4 \mathrm{~A}$ schematically illustrates the contribution of the various ion channels to the ventricular action potential.

Connexin 43 is the main gap junction protein responsible for sodium influx during phase 0 of the action potential and subsequently conduction velocity. Increased lateralization of $\mathrm{C} x 43$ in the left ventricle is associated with remodelling processes after tachypacinginduced HF and after myocardial infarction (Figure 5). ${ }^{101,102}$ Interestingly, electrical dyssynchrony by itself already influences $\mathrm{C} \times 43$ localization. In the lateral segments of the canine LBBB heart, a reduced endocardial conduction velocity was observed in combination with lateralization of $\mathrm{C} \times 43 .{ }^{95}$ Lateralization of $\mathrm{C} \times 43$ may lead to a more zig-zag conduction pattern, ${ }^{103}$ and consequently slower conduction, heterogeneity of refractoriness, and increased risk of reentry circuits. In addition, in canine hearts with tachypacinginduced HF both lateralization and decreased expression of $\mathrm{C} \times 43$ were associated with slowing of His-Purkinje conduction duration (Figure 4B), ${ }^{104}$ indicating that remodelling processes secondary to HF solely already prolong QRS duration.

Another factor contributing to conduction and cardiac excitation is the fast-inward voltage-dependent sodium channel $\left(l_{\mathrm{Na}}\right)$, but its role in dyssynchrony is unequivocal. $I_{\mathrm{Na}}$ density was decreased in explanted human hearts with $\mathrm{HF}^{105}$ but contradictory results have been reported for canine hearts with tachypacing-induced HF. ${ }^{105,106}$

While changes in the QRS complex reflect changes in depolarization, T-wave changes reflect altered repolarization. In this respect, 'cardiac memory' is of interest. Cardiac memory refers to persistent T-wave changes on the ECG during restoration of normal ventricular activation sequence after a period of abnormal ventricular activation. These persistent $\mathrm{T}$-wave abnormalities indicate that the sequence of repolarization adapts to a new activation sequence. ${ }^{107}$ This phenomenon has been studied in animals and humans. ${ }^{108,109}$ In patients with $\mathrm{RV}$ pacing, changes in T-wave amplitude and duration were already present within one day of pacing and became persistent after 1 week. ${ }^{110}$ Similar cardiac memory phenomena developed between 1 day and 2 weeks of CRT. ${ }^{111}$ Interestingly, animal studies showed that cardiac memory could be suppressed by mechanical unloading of the heart. ${ }^{108}$ At the molecular level, involvement of the L-type calcium channel ${ }^{112}$ and the cyclic adenosine monophosphate response element binding protein, a factor heavily involved in regulation of gene expression, was shown. ${ }^{113}$ These results strongly argue that the ventricular repolarization changes underlying cardiac memory are related to the mechanical consequences of the activation sequence ('mechano-electrical feedback'). 
A

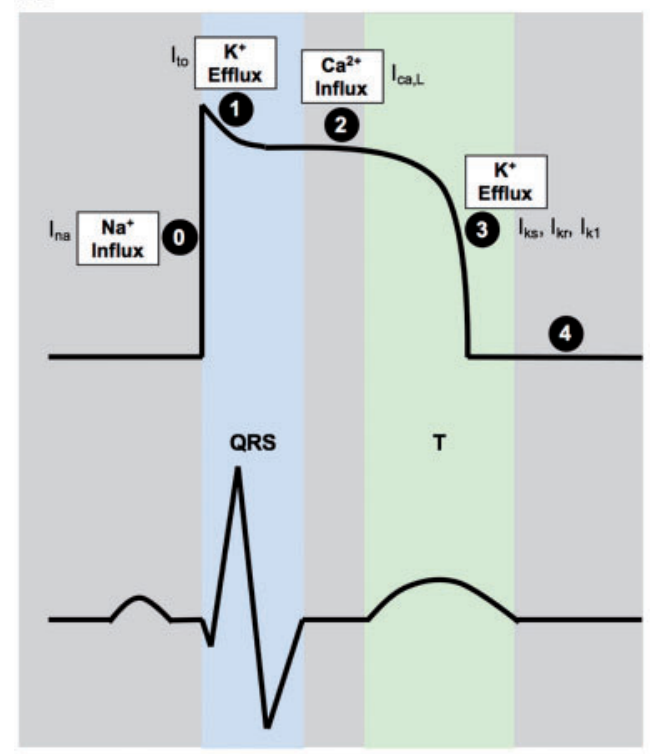

B
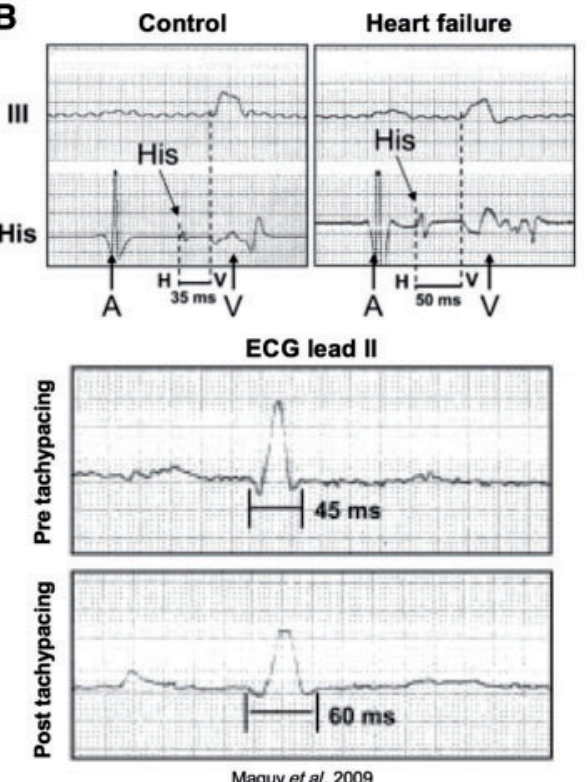

Figure 4 (A) Schematic overview of the five phases of the action potential, ECG, and ion channels involved. The action potential consists of: phase 0 (upstroke), phase 1 (fast early depolarization), phase 2 (plateau), phase 3 (repolarization), and phase 4 (resting membrane potential). (B) ECG and His electrograms demonstrating increase in HV-interval and QRS duration after tachypacing-induced heart failure in canine hearts (adapted with permission from Maguy et al. $\left.{ }^{104}\right)$. ECG, electrocardiogram.
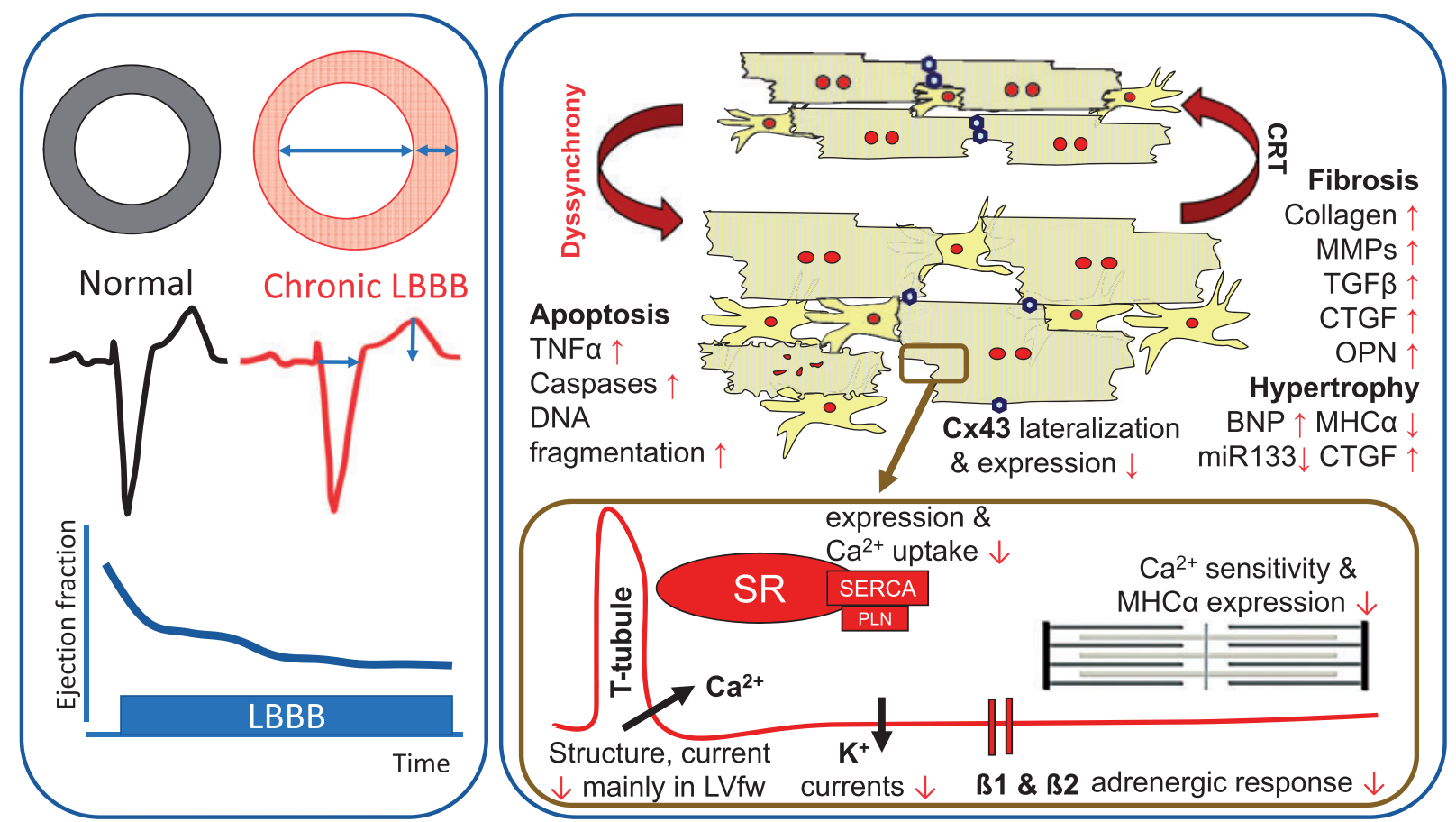

Figure 5 Processes contributing to the structural, electrical, and contractile remodelling in the dyssynchronous heart as seen on functional measurements (left) and on a cellular and molecular level (right). Red colour indicates the situation during dyssynchrony. Dyssynchrony causes asymmetric, eccentric hypertrophy, and (in the failing heart) fibrosis as well as apoptosis. Some of the molecular factors are mentioned. Similarly, some of the processes involved in altered excitation-contraction coupling are displayed in the inset, illustrating a part of the plasmalemma, T-tubule and SR (see text for further details). BNP, B-type natriuretic peptide; CRT, cardiac resynchronization therapy; CTGF, connective tissue growth factor; Cx43, connexin 43; LBBB, left bundle branch block; LVfw, LV free wall; MHC $\alpha$, myosin heavy chain $\alpha$; MMP, matrix metalloproteases; OPN, osteopontin; PLN, phospholamban; SR, sarcoplasmic reticulum; SERCA, SR Ca ${ }^{2+}$ ATP-ase; TGF $\beta$, transforming growth factor beta; TNF $\alpha$, tumor necrosis factor alpha. 
While the T-wave changes in the setting of cardiac memory are indicative of changes in action potential duration (APD), such APD changes have indeed been observed in normal animal hearts during longer lasting periods of ventricular pacing. ${ }^{114,115}$ These studies showed APD lengthening in early-activated regions and gradual APD lengthening towards later activated regions. However, in the very latest activated regions the APD lengthened in the dog heart, ${ }^{115}$ whereas it was shortened in rabbit hearts. ${ }^{114}$

Commonly, the upright 'concordant' T-wave in the normal ECG is explained by late-activated regions having a shorter APD than earlyactivated regions. ${ }^{116}$ While cardiac memory indicates some potential of the ventricles to adapt APD to activation sequence, the usually discordant $\mathrm{T}$-wave in hearts with $\mathrm{RV}$ pacing and LBBB suggests that this potential to adjust APD is insufficient in case of severe dyssynchrony. However, studies in patients without HF show that during longer lasting dyssynchrony (RV pacing and LBBB), the amplitude of the T-wave decreases over time, ${ }^{109,117,118}$ suggesting some adaptation to the abnormal conduction. However, a recent electrical mapping study in HF patients showed that, regardless of QRS duration and morphology, the sequence of repolarization largely follows the sequence of activation, pointing towards reduced 'capacity' of failing myocardium to adjust APD to abnormal activation sequence. ${ }^{119}$

Concordant with the experimentally observed role of the L-type calcium channel in cardiac memory, data from tachypaced dyssynchronous dog hearts show differential expression and current flow of this calcium channel, with lower values in the LV lateral than in the anterior wall. ${ }^{82}$ However, while larger L-type calcium currents are expected to prolong APD, in the same study APD was shorter in myocytes from earlier-activated LV anterior wall regions. ${ }^{82}$ The investigators explain this paradox by referring to the slower decay in the current in the LV lateral wall. In addition, the severe, but uniform reduction in various potassium channels (important during phase 3 and 4 of the action potential, Figure 4A), may change the influence of the various ion channels during the repolarization phase. ${ }^{82}$

Computer model studies investigated how to reconcile the aforementioned mechano-electrical feedback, observed in cardiac memory studies, and the electrical and contractile remodelling in dyssynchronous hearts. It was assumed that mechano-sensing aims to maintain a constant mechanical function (like strain), and that adjustments occur through varying activity of the L-type calcium current. ${ }^{82}$ According to the computer simulation, a reduction in local mechanics in early activated regions was followed by increased activity of the L-type calcium channel. ${ }^{120}$ During small time differences in activation (e.g. sinus rhythm), this adaptation process was able to lead to the well-known concordant T-wave. ${ }^{120}$ In the dyssynchronous ventricle, T-waves only became less discordant over time, ${ }^{121}$ much like what has been observed in patients (see above).

Clearly, our understanding of electrical remodelling processes influencing ventricular repolarization in the dyssynchronous heart is incomplete. Beside factors discussed above, also the poor understanding of electrotonic influences on repolarization in vivo and of the relation between APD heterogeneity and T-wave morphology should be recognized. ${ }^{116,119}$

\section{Contractile remodelling}

Dyssynchrony results in acute negative effects on LV contractile function in animals ${ }^{69}$ and patients. ${ }^{122}$ Moreover, a study in patients with normal LVEF showed that RV pacing immediately reduces LVEF by $\sim 6 \%$, followed by a further $\sim 8 \%$ during the subsequent week of RV pacing. Full recovery of LVEF after termination of pacing took 2 days, further indicating some kind of contractile remodelling. ${ }^{123}$ Similarly, CRT reverses some of the contractile defects beat-to-beat ${ }^{124,125}$ and continues to do so over years. ${ }^{69,126}$

While the acute hemodynamic effects can be explained by changes in mechanical coordination, as explained above, the chronic effects seem mediated by subcellular and molecular changes. ${ }^{4}$ In this regard calcium probably plays a dual role, also being involved in electrical remodelling. As mentioned above, in the tachypacing model LBBB lead to a significant and regionally different reduction in the L-type calcium current and this disparity was resolved by tachypacing $\mathrm{CRT}^{82}$ L-type calcium current densities were also reduced in ventricular myocytes from a minipig model of RV pacing, compared with controls. $^{127}$

Also, other proteins involved in calcium handling may play a role in contractile remodelling. Patients with ischaemic or idiopathic dilated cardiomyopathy show reduced sarcoplasmatic reticulum (SR) $\mathrm{Ca}^{2+}$ ATP-ase (SERCA) activity compared with controls. ${ }^{128}$ Lower SERCA expression was found in patients who are eligible for $\mathrm{CRT}^{96}$ and CRT increases SERCA expression. ${ }^{129,130}$ Vanderheyden et al. ${ }^{96}$ showed that the increase in SERCA only occurs in CRT responders. Several, ${ }^{129,130}$ albeit not all studies report an increase in phospholamban (PLN) levels after CRT. ${ }^{96}$

These clinical data fit with observations of reduced SR calcium uptake in a porcine model of RV pacing ${ }^{99}$ and down-regulation of SERCA in tachypaced ${ }^{82}$ and non-tachypaced ${ }^{131}$ dog hearts. In one study, the change occurred in the LVFW but not in the interventricular septum. ${ }^{131}$ In the LVFW of tachypaced dyssynchronous HF a reduction in SERCA expression was selectively found in the endocardium, leading to a steep transmural expression gradient. ${ }^{80}$ After tachy-CRT, SERCA was no longer significantly down-regulated in either early or late activated myocardium. ${ }^{82}$ Slightly smaller, but still significant reductions were observed for PLN in both tachypaced and non-tachypaced canine models of dyssynchrony, ${ }^{82,131}$ but not in a porcine model. ${ }^{99}$

An upregulation of the sodium-calcium exchanger was found in animal models of (tachy) dyssynchrony ${ }^{82,99}$ and a similar trend could be observed after CRT in patients. ${ }^{130}$

These molecular changes may relate to subcellular changes. In patients, abnormalities in $\mathrm{T}$ tubular structure have been linked to impaired contractility. ${ }^{132}$ In the LV lateral wall of the tachypacing LBBB model, regression of the T-tubular system has been reported, which was partially reversible upon tachy-CRT. ${ }^{133,134}$

An important role in the contractile remodelling processes may also be reserved for the autonomic nervous system. The response to $\beta$-adrenergic stimulation is diminished in patients with $\mathrm{HF}^{135}$ Cardiac resynchronization therapy treatment recovers the $\beta$-adrenergic response. $^{136}$

On the cellular level, the contractile response to $\beta$-adrenergic stimulation (increase in calcium transient, cellular shortening) is reduced in $\mathrm{HF},{ }^{137}$ which may be (partially) explained by downregulation of the $\beta 1$ and $\beta 2$ adrenergic receptors. ${ }^{138,139}$ In tachypaced dyssynchronous HF, tachy-CRT normalizes the response in cells from both anterior and lateral LV wall. ${ }^{138,139}$ Interestingly, most studies, in both patients ${ }^{130}$ and animals, ${ }^{138,139}$ demonstrate that CRT 
upregulates the $\beta 1$-, but not the $\beta 2$-receptor. In addition, a unique feature of $\beta 2$-receptor signalling is observed during dyssynchrony being an increased G-protein alpha-I $\left(G \alpha_{i}\right)$ coupling, leading to reduced adenylyl cyclase activity and thus lowering cyclic AMP production. This contributes to decreased contractile function. Upon resynchronization, the $\beta 2$ receptor becomes uncoupled from these $\mathrm{G} \alpha_{i}$ proteins and restores $\mathrm{G} \alpha_{s}$ signalling. ${ }^{138}$ This this mechanism may also be active in CRT responders. ${ }^{138}$

Also at the level of the myofibrils, some remodelling may be present, for instance in myosin heavy chain $\alpha(\mathrm{MHC} \alpha)$. In patients, dyssynchronous $\mathrm{HF}$ is associated with reduced expression of MHC $\alpha$ and this reduction seems reversed by $\mathrm{CRT} .^{96,129}$ The CRT-induced $\mathrm{MHC} \alpha$-increase correlated with the reduction in cavity dimensions. ${ }^{129}$

Studies in skinned muscle fibres from animals with tachypacinginduced HF showed yet another mechanism of contractile modulation: calcium sensitivity of the myofilaments. This sensitivity was shown to be reduced in dyssynchronous HF due to glycogen synthase kinase (GSK)-3 $\beta$ — dependent phosphorylation of contractile proteins. Tachy-CRT restored calcium sensitivity through increased GSK3-ß activity. ${ }^{140}$

Summarizing, a large range of processes seem responsible for the contractile remodelling processes in dyssynchrony and its reversal upon CRT, which are depicted in Figure 5.

\section{Conclusion}

This review illustrates that conduction abnormalities (such as LBBB) lead to extensive immediate and long-term changes in the heart and reversal of functions by CRT. The long-term adaptations of the myocardium can be characterized as 'maladaptive' because many functions continue to decrease over time. This also explains why CRT, unlike most pharmacological treatments, continues to increase its therapeutic effect over time.

\section{Funding}

U.C.N. received a Kootstra Talent Fellowship research grant from Maastricht University and was additionally funded by a research grant from the Dutch Heart Foundation (2015T61). The funders had no role in preparation of the manuscript.

Conflict of interest: K.V. reports consultancy for Medtronic; research grants from Medtronic; speaker fees from St. Jude Medical. F.W.P. reports having received research grants from Medtronic, St Jude Medical, LivaNova, Biotronik, Sorin, Biosense Webster and EBR Systems. The authors declare that no competing interests exist.

\section{References}

1. Myerburg RJ, Gelband H, Nilsson K, Castellanos A, Morales AR, Bassett AL. The role of canine superficial ventricular muscle fibers in endocardial impulse distribution. Circ Res 1978;42:27-35.

2. Ono N, Yamaguchi T, Ishikawa H, Arakawa M, Takahashi N, Saikawa T. Morphological varieties of the Purkinje fiber network in mammalian hearts, as revealed by light and electron microscopy. Arch Histol Cytol 2009;72:139-49.

3. Oosthoek PW, Viragh S, Lamers WH, Moorman AF. Immunohistochemical delineation of the conduction system. II: the atrioventricular node and Purkinje fibers. Circ Res 1993;73:482-91.

4. Strik M, Rademakers LM, van Deursen CJ, van Hunnik A, Kuiper M, Klersy C et al. Endocardial left ventricular pacing improves cardiac resynchronization therapy in chronic asynchronous infarction and heart failure models. Circ Arrhythm Electrophysiol 2012;5:191-200.
5. Frazier OH, Macris MP, Duncan JM, Van Buren CT, Cooley DA. Cardiac transplantation in patients over 60 years of age. Ann Thorac Surg 1988;45:129-32.

6. Hyde ER, Behar JM, Claridge S, Jackson T, Lee AW, Remme EW et al. Beneficial effect on cardiac resynchronization from left ventricular endocardial pacing is mediated by early access to high conduction velocity tissue: electrophysiological simulation study. Circ Arrhythm Electrophysiol 2015;8:1164-72.

7. Taccardi B, Punske BB, Macchi E, Macleod RS, Ershler PR. Epicardial and intramural excitation during ventricular pacing: effect of myocardial structure. Am J Physiol Heart Circ Physiol 2008;294:H1753-66.

8. Derval N, Jais P. Optimizing hemodynamics in cardiac resynchronization therapy by left ventricular pacing site: you find only what you are looking for. J Am Coll Cardiol 2010;56:782-3.

9. Durrer D, van Dam RT, Freud GE, Janse MJ, Meijler FL, Arzbaecher RC. Total excitation of the isolated human heart. Circulation 1970;41:899-912.

10. Spach MS, Miller WT 3rd, Geselowitz DB, Barr RC, Kootsey JM, Johnson EA. The discontinuous nature of propagation in normal canine cardiac muscle. Evidence for recurrent discontinuities of intracellular resistance that affect the membrane currents. Circ Res 1981;48:39-54.

11. Demoulin JC, Kulbertus HE. Histopathological examination of concept of left hemiblock. Br Heart J 1972;34:807-14.

12. Eriksson P, Hansson PO, Eriksson H, Dellborg M. Bundle-branch block in a general male population: the study of men born 1913. Circulation 1998;98:2494-500.

13. El-Sherif N, Amay YLF, Schonfield C, Scherlag BJ, Rosen K, Lazzara R et al. Normalization of bundle branch block patterns by distal His bundle pacing. Clinical and experimental evidence of longitudinal dissociation in the pathologic his bundle. Circulation 1978;57:473-83.

14. Narula OS, Javier RP, Samet P, Maramba LC. Significance of His and left bundle recordings from the left heart in man. Circulation 1970;42:385-96.

15. Narula OS. Longitudinal dissociation in the His bundle. Bundle branch block due to asynchronous conduction within the His bundle in man. Circulation 1977; 56:996-1006.

16. Ajijola OA, Upadhyay GA, Macias C, Shivkumar K, Tung R. Permanent Hisbundle pacing for cardiac resynchronization therapy: initial feasibility study in lieu of left ventricular lead. Heart Rhythm 2017;14:1353-61.

17. Vassallo JA, Cassidy DM, Miller JM, Buxton AE, Marchlinski FE, Josephson ME. Left ventricular endocardial activation during right ventricular pacing: effect of underlying heart disease. J Am Coll Cardiol 1986;7:1228-33.

18. Fantoni C, Kawabata M, Massaro R, Regoli F, Raffa S, Arora $\vee$ et al. Right and left ventricular activation sequence in patients with heart failure and right bundle branch block: a detailed analysis using three-dimensional non-fluoroscopic electroanatomic mapping system. J Cardiovasc Electrophysiol 2005;16:112-9; discussion 120-1.

19. Auricchio A, Fantoni C, Regoli F, Carbucicchio C, Goette A, Geller C et al. Characterization of left ventricular activation in patients with heart failure and left bundle-branch block. Circulation 2004;109:1133-9.

20. Prinzen FW, Auricchio A. Is echocardiographic assessment of dyssynchrony useful to select candidates for cardiac resynchronization therapy? Echocardiography is not useful before cardiac resynchronization therapy if QRS duration is available. Circ Cardiovasc Imaging 2008;1:70-7; discussion 78.

21. Strik M, van Deursen CJ, van Middendorp LB, van Hunnik A, Kuiper M, Auricchio $A$ et al. Transseptal conduction as an important determinant for cardiac resynchronization therapy, as revealed by extensive electrical mapping in the dyssynchronous canine heart. Circ Arrhythm Electrophysiol 2013;6:682-9.

22. Ploux S, Lumens J, Whinnett Z, Montaudon M, Strom M, Ramanathan C et al Noninvasive electrocardiographic mapping to improve patient selection for cardiac resynchronization therapy: beyond QRS duration and left bundle branch block morphology. J Am Coll Cardiol 2013;61:2435-43.

23. Strauss DG, Selvester RH, Wagner GS. Defining left bundle branch block in the era of cardiac resynchronization therapy. Am J Cardiol 2011;107:927-34.

24. Brignole M, Auricchio A, Baron-Esquivias G, Bordachar P, Boriani G, Breithardt OA et al. 2013 ESC guidelines on cardiac pacing and cardiac resynchronization therapy: the task force on cardiac pacing and resynchronization therapy of the European Society of Cardiology (ESC). Developed in collaboration with the European Heart Rhythm Association (EHRA). Europace 2013;15:1070-118.

25. van Deursen CJ, Blaauw Y, Witjens MI, Debie L, Wecke L, Crijns HJ et al. The value of the 12-lead ECG for evaluation and optimization of cardiac resynchronization therapy in daily clinical practice. J Electrocardiol 2014;47:202-11.

26. Jurak P, Halamek J, Meluzin J, Plesinger F, Postranecka T, Lipoldova J et al. Ventricular dyssynchrony assessment using ultra-high frequency ECG technique. J Interv Card Electrophysiol 2017;49:245-54.

27. van Deursen CJ, Vernooy K, Dudink E, Bergfeldt L, Crijns HJ, Prinzen FW et al. Vectorcardiographic QRS area as a novel predictor of response to cardiac resynchronization therapy. J Electrocardiol 2015;48:45-52.

28. Ramanathan C, Ghanem RN, Jia P, Ryu K, Rudy Y. Noninvasive electrocardiographic imaging for cardiac electrophysiology and arrhythmia. Nat Med 2004;10 422-8. 
29. Huntjens PR, Ploux S, Strik M, Walmsley J, Ritter P, Haissaguerre M et al. Electrical substrates driving response to cardiac resynchronization therapy: a combined clinical—computational evaluation. Circ Arrhythm Electrophysiol 2018; in press.

30. Gage RM, Curtin AE, Burns KV, Ghosh S, Gillberg JM, Bank AJ. Changes in electrical dyssynchrony by body surface mapping predict left ventricular remodeling in patients with cardiac resynchronization therapy. Heart Rhythm 2017;14: 392-9.

31. Wyman BT, Hunter WC, Prinzen FW, McVeigh ER. Mapping propagation of mechanical activation in the paced heart with MRI tagging. Am J Physiol 1999; 276:H881-91.

32. Wyman BT, Hunter WC, Prinzen FW, Faris OP, McVeigh ER. Effects of singleand biventricular pacing on temporal and spatial dynamics of ventricular contraction. Am J Physiol 2002;282:H372-9.

33. Kroon W, Lumens J, Potse M, Suerder D, Klersy C, Regoli F. In vivo electromechanical assessment of heart failure patients with prolonged QRS duration. Heart Rhythm 2015;12:1259-67.

34. Mafi Rad M, van't Sant J, Blaauw Y, Meijboom FJ, Doevendans PA, Cramer MJ. Regional left ventricular electrical activation and contraction are closely related in candidates for cardiac resynchronization therapy. JACC Clin Electrophysiol 2017;3:854-62.

35. Lumens J, Leenders GE, Cramer MJ, De Boeck BW, Doevendans PA, Prinzen FW et al. Mechanistic evaluation of echocardiographic dyssynchrony indices: patient data combined with multiscale computer simulations. Circ Cardiovasc Imaging 2012;5:491-9.

36. De Boeck BW, Teske AJ, Meine M, Leenders GE, Cramer MJ, Prinzen FW et al. Septal rebound stretch reflects the functional substrate to cardiac resynchronization therapy and predicts volumetric and neurohormonal response. Eur J Heart Fail 2009;11:863-71.

37. Leenders GE, Lumens J, Cramer MJ, De Boeck BWL, Doevendans PA, Delhaas $T$ et al. Septal deformation patterns delineate mechanical dyssynchrony and regional differences in contractility: analysis of patient data using a computer model. Circ Heart Fail 2012;5:87-96.

38. Bleeker GB, Schalij MJ, Molhoek SG, Verwey HF, Holman ER, Boersma E et al. Relationship between QRS duration and left ventricular dyssynchrony in patients with end-stage heart failure. J Cardiovasc Electrophysiol 2004;15:544-9.

39. Hara H, Oyenuga OA, Tanaka H, Adelstein EC, Onishi T, McNamara DM et al. The relationship of QRS morphology and mechanical dyssynchrony to long-term outcome following cardiac resynchronization therapy. Eur Heart J 2012;33:2680-91.

40. Bilchick KC, Dimaano V, Wu KC, Helm RH, Weiss RG, Lima JA et al. Cardiac magnetic resonance assessment of dyssynchrony and myocardial scar predicts function class improvement following cardiac resynchronization therapy. JACC Cardiovasc Imaging 2008;1:561-8.

41. Onishi T, Saha SK, Ludwig DR, Onishi T, Marek J), Cavalcante JL et al. Feature tracking measurement of dyssynchrony from cardiovascular magnetic resonance cine acquisitions: comparison with echocardiographic speckle tracking. J Cardiovasc Magn Reson 2013;15:95.

42. Behar JM, Rajani R, Pourmorteza A, Preston R, Razeghi O, Niederer S et al. Comprehensive use of cardiac computed tomography to guide left ventricular lead placement in cardiac resynchronization therapy. Heart Rhythm 2017;14: 1364-72.

43. Chung ES, Leon AR, Tavazzi L, Sun JP, Nihoyannopoulos P, Merlino J et al. Results of the Predictors of Response to CRT (PROSPECT) trial. Circulation 2008;117:2608-16.

44. Seo Y, Ito H, Nakatani S, Takami N, Naito S, Shiga T et al. The role of echocardiography in predicting responders to cardiac resynchronization therapy: results from the Japan Cardiac Resynchronization therapy registry Trial (J-CRT). Circ J 2011:75:1156-63.

45. Ruschitzka M, Abraham WT, Singh JP, Bax JJ, Borer JS, Brugada J et al. Cardiacresynchronization therapy in heart failure with a narrow QRS complex. N Engl J Med 2013;369:1395-405.

46. Beshai JF, Grimm RA, Nagueh SF, Baker JH, Beau SL, Greenberg SM et al. Cardiac-resynchronization therapy in heart failure with narrow QRS complexes. N Engl J Med 2007;357:2461-71.

47. De Boeck BWL, Meine M, Leenders GE, Teske AJ, Van Wessel H, Kirkels JH et al. Practical and conceptual limitations of tissue Doppler imaging to predict reverse remodelling in cardiac resynchronisation therapy. Eur J Heart Failure 2008;10:281-90.

48. Lumens J, Tayal B, Walmsley J, Delgado-Montero A, Huntjens PR, Saba S et al. Differentiating the electromechanical substrate responsive to cardiac resynchronization therapy from non-electrical dyssynchrony substrates by computerassisted regional strain analysis. Circ Cardiovasc Imaging 2015;8:e003744.

49. Parsai C, Bijnens B, Sutherland GR, Baltabaeva A, Claus P, Marciniak M et al. Toward understanding response to cardiac resynchronization therapy: left ventricular dyssynchrony is only one of multiple mechanisms. Eur Heart J 2009;30: 940-9.
50. Stankovic I, Prinz C, Ciarka A, Daraban AM, Kotrc M, Aarones M et al. Relationship of visually assessed apical rocking and septal flash to response and long-term survival following cardiac resynchronization therapy (PREDICTCRT). Eur Heart J Cardiovasc Imaging 2016;17:262-9.

51. Maass AH, Vernooy K, Wijers SC, van 't Sant J, Cramer MJ, Meine M et al. Refining success of cardiac resynchronization therapy using a simple score predicting the amount of reverse ventricular remodelling: results from the Markers and Response to CRT (MARC) study. Europace 2018;20:e1-10.

52. Risum N, Strauss D, Sogaard P, Loring Z, Hansen TF, Bruun NE et al. Left bundlebranch block: the relationship between electrocardiogram electrical activation and echocardiography mechanical contraction. Am Heart / 2013;166:340-8.

53. Bilchick KC, Kuruvilla S, Hamirani YS, Ramachandran R, Clarke SA, Parker KM et al. Impact of mechanical activation, scar, and electrical timing on cardiac resynchronization therapy response and clinical outcomes. J Am Coll Cardiol 2014;63:1657-66

54. Leenders GE, De Boeck BW, Teske AJ, Meine M, Bogaard MD, Prinzen FW et al. Septal rebound stretch is a strong predictor of outcome after cardiac resynchronization therapy. J Card Fail 2012;18:404-12.

55. van Oosterhout MF, Prinzen FW, Arts T, Schreuder JJ, Vanagt WY, Cleutjens JP et al. Asynchronous electrical activation induces asymmetrical hypertrophy of the left ventricular wall. Circulation 1998;98:588-95.

56. Steendijk P, Tulner SA, Bax J, Oemrawsingh PV, Bleeker GB, van Erven L et al. Hemodynamic effects of long-term cardiac resynchronization therapy: analysis by pressure-volume loops. Circulation 2006;113:1295-304.

57. Prinzen FW, Hunter WC, Wyman BT, McVeigh ER. Mapping of regional myocardial strain and work during ventricular pacing: experimental study using Magnetic Resonance Imaging tagging. J Am Coll Cardiol 1999;33:1735-42.

58. Russell K, Eriksen M, Aaberge L, Wilhelmsen N, Skulstad H, Remme EW et al. A novel clinical method for quantification of regional left ventricular pressurestrain loop area: a non-invasive index of myocardial work. Eur Heart J 2012;33 724-33.

59. Russell K, Eriksen M, Aaberge L, Wilhelmsen N, Skulstad H, Gjesdal O et al. Assessment of wasted myocardial work: a novel method to quantify energy loss due to uncoordinated left ventricular contractions. Am J Physiol Heart Circ Physio 2013;305:H996-1003.

60. Aalen J, Storsten P, Remme EW, Sirnes PA, Gjesdal O, Larsen CK et al Afterload hypersensitivity in patients with left bundle branch block. JACC Cardiovasc Imaging 2017; doi:10.1016/j.jcmg.2017.11.025.

61. Mills RW, Cornelussen RN, Mulligan LJ, Strik M, Rademakers LM, Skadsberg ND et al. Left ventricular septal and left ventricular apical pacing chronically maintain cardiac contractile coordination, pump function and efficiency. Circ Arrhythm Electrophysiol 2009;2:571-9.

62. Nelson GS, Berger RD, Fetics BJ, Talbot M, Spinelli C, Hare JM et al. Left ventricular or biventricular pacing improves cardiac function at diminished energy cost in patients with dilated cardiomyopathy and left bundle-branch block. Circulation 2000;102:3053-9.

63. Lindner O, Vogt J, Kammeier A, Wielepp P, Holzinger J, Baller D et al. Effect of cardiac resynchronization therapy on global and regional oxygen consumption and myocardial blood flow in patients with non-ischaemic and ischaemic cardiomyopathy. Eur Heart J 2005;26:70-6.

64. Kyriacou A, Pabari PA, Mayet J, Peters NS, Davies DW, Lim PB et al. Cardiac resynchronization therapy and $\mathrm{AV}$ optimization increase myocardial oxygen consumption, but increase cardiac function more than proportionally. Int J Cardiol 2014;171:144-52.

65. Knaapen P, van Campen LM, de Cock CC, Gotte MJ, Visser CA, Lammertsma AA et al. Effects of cardiac resynchronization therapy on myocardial perfusion reserve. Circulation 2004;110:646-51.

66. Vecera J, Penicka M, Eriksen M, Russell K, Bartunek J, Vanderheyden M et al. Wasted septal work in left ventricular dyssynchrony: a novel principle to predict response to cardiac resynchronization therapy. Eur Heart J Cardiovasc Imaging 2016;17:624-32.

67. Zweerink A, de Roest G], Wu L, Nijveldt R, de Cock CC, van Rossum AC et al. Prediction of acute response to cardiac resynchronization therapy by means of the misbalance in regional left ventricular myocardial work. J Card Fail 2016;22 $133-42$.

68. Vernooy K, Verbeek XA, Peschar M, Crijns HJ, Arts T, Cornelussen RN et al. Left bundle branch block induces ventricular remodelling and functional septal hypoperfusion. Eur Heart J 2005;26:91-8.

69. Vernooy K, Cornelussen RN, Verbeek XA, Vanagt WY, van Hunnik A, Kuiper $M$ et al. Cardiac resynchronization therapy cures dyssynchronopathy in canine left bundle-branch block hearts. Eur Heart J 2007;28:2148-55.

70. Amitzur G, Manor D, Pressman A, Adam D, Hammerman H, Shofti R et al. Modulation of the arterial coronary blood flow by asynchronous activation with ventricular pacing. Pacing Clin Electrophysiol 1995;18:697-710.

71. Kirk JA, Kass DA. Cellular and molecular aspects of dyssynchrony and resynchronization. Heart Fail Clin 2017;13:29-41. 
72. Wiegerinck RF, Schreurs R, Prinzen FW. Pathophysiology of dyssynchrony: of squirrels and broken bones. Neth Heart J 2016;24:4-10.

73. Vanderheyden M, Vrints C, Bartunek J. The molecular fingerprint of cardiac dyssynchrony and cardiac resynchronization therapy. Heart Fail Rev 2011;16: 227-33.

74. van Berlo $\mathrm{JH}$, Maillet M, Molkentin JD. Signaling effectors underlying pathologic growth and remodeling of the heart. J Clin Invest 2013;123:37-45.

75. Heineke J, Molkentin JD, Regulation of cardiac hypertrophy by intracellular signalling pathways. Nat Rev Mol Cell Biol 2006;7. 589-600.

76. Blaauw E, Lorenzen-Schmidt I, Babiker FA, Munts C, Prinzen FW, Snoeckx LH et al. Stretch-induced upregulation of connective tissue growth factor in rabbit cardiomyocytes. J Cardiovasc Transl Res 2013;6:861-9.

77. Blaauw E, van Nieuwenhoven FA, Willemsen P, Delhaas T, Prinzen FW, Snoeckx LH et al. Stretch-induced hypertrophy of isolated adult rabbit cardiomyocytes. Am J Physiol Heart Circ Physiol 2010;299:H780-7.

78. Herum KM, Choppe J, Kumar A, Engler AJ, McCulloch AD. Mechanical regulation of cardiac fibroblast profibrotic phenotypes. Mol Biol Cell 2017;28:1871-82.

79. Strik M, van Middendorp LB, Vernooy K. Animal models of dyssynchrony. J Cardiovasc Transl Res 2012;5:135-45.

80. Spragg DD, Leclercq C, Loghmani M, Faris OP, Tunin RS, DiSilvestre D et al. Regional alterations in protein expression in the dyssynchronous failing heart. Circulation 2003;108:929-32.

81. Nishijima Y, Sridhar A, Viatchenko-Karpinski S, Shaw C, Bonagura JD, Abraham WT et al. Chronic cardiac resynchronization therapy and reverse ventricular remodeling in a model of nonischemic cardiomyopathy. Life Sci 2007;81:1152-9.

82. Aiba T, Hesketh GG, Barth AS, Liu T, Daya S, Chakir K et al. Electrophysiological consequences of dyssynchronous heart failure and its restoration by resynchronization therapy. Circulation 2009;119:1220-30.

83. Akar FG, Spragg DD, Tunin RS, Kass DA, Tomaselli GF. Mechanisms underlying conduction slowing and arrhythmogenesis in nonischemic dilated cardiomyopathy. Circ Res 2004;95: 717-25.

84. St John Sutton MG, Plappert T, Abraham WT, Smith AL, DeLurgio DB, Leon $A R$ et al. Effect of cardiac resynchronization therapy on left ventricular size and function in chronic heart failure. Circulation 2003;107:1985-90.

85. Yu CM, Bleeker GB, Fung JW, Schalij MJ, Zhang Q, van der Wall EE et al. Left ventricular reverse remodeling but not clinical improvement predicts long-term survival after cardiac resynchronization therapy. Circulation 2005;112:1580-6.

86. D'Ascia C, Cittadini A, Monti MG, Riccio G, Sacca L. Effects of biventricular pacing on interstitial remodelling, tumor necrosis factor-alpha expression, and apoptotic death in failing human myocardium. Eur Heart J 2006;27:201-6.

87. Orrego CM, Nasir N, Oliveira GH, Flores-Arredondo JH, Cordero-Reyes AM, Loebe $M$ et al. Cellular evidence of reverse cardiac remodeling induced by cardiac resynchronization therapy. Congest Heart Fail 2011;17:140-6.

88. Zhang Q, Fung JW, Auricchio A, Chan JY, Kum LC, Wu LW et al. Differential change in left ventricular mass and regional wall thickness after cardiac resynchronization therapy for heart failure. Eur Heart J 2006;27:1423-30.

89. Soliman OI, Geleijnse ML, Theuns DA, Nemes A, Vletter WB, van Dalen BM et al. Reverse of left ventricular volumetric and structural remodeling in heart failure patients treated with cardiac resynchronization therapy. Am J Cardiol 2008;101:651-7.

90. Schmitz B, De Maria R, Gatsios D, Chrysanthakopoulou T, Landolina M, Gasparini $M$ et al. Identification of genetic markers for treatment success in heart failure patients: insight from cardiac resynchronization therapy. Circ Cardiovasc Genet 2014;7:760-70.

91. De Maria R, Landolina M, Gasparini M, Schmitz B, Campolo J, Parolini M et al. Genetic variants of the renin-angiotensin-aldosterone system and reverse remodeling after cardiac resynchronization therapy. J Card Fail 2012;18:762-8.

92. van Middendorp LB, Kuiper M, Munts C, Wouters P, Maessen JG, van Nieuwenhoven FA et al. Local microRNA-133a downregulation is associated with hypertrophy in the dyssynchronous heart. ESC Heart Failure 2017;4: 241-51.

93. Lin JM, Lai LP, Lin CS, Chou NK, Chiu CY, Lin JL. Left ventricular extracellular matrix remodeling in dogs with right ventricular apical pacing. J Cardiovasc Electrophysiol 2010;21:1142-9.

94. Wang J, Gong X, Chen H, Qin S, Zhou N, Su Y et al. Effect of cardiac resynchronization therapy on myocardial fibrosis and relevant cytokines in a canine model with experimental heart failure. J Cardiovasc Electrophysiol 2017;28: 438-45.

95. Spragg DD, Akar FG, Helm RH, Tunin RS, Tomaselli GF, Kass DA. Abnormal conduction and repolarization in late-activated myocardium of dyssynchronously contracting hearts. Cardiovasc Res 2005;67:77-86.

96. Vanderheyden M, Mullens W, Delrue L, Goethals M, de Bruyne B, Wijns W et al. Myocardial gene expression in heart failure patients treated with cardiac resynchronization therapy responders versus nonresponders. J Am Coll Cardiol 2008;51:129-36.
97. Chakir K, Daya SK, Tunin RS, Helm RH, Byrne MJ, Dimaano VL et al. Reversal of global apoptosis and regional stress kinase activation by cardiac resynchronization. Circulation 2008;117:1369-77.

98. Marin-Garcia J, Goldenthal MJ, Damle S, Pi Y, Moe GW. Regional distribution of mitochondrial dysfunction and apoptotic remodeling in pacing-induced heart failure. J Card Fail 2009;15:700-8.

99. Klug D, Boule S, Wissocque L, Montaigne D, Marechal X, Hassoun SM et al. Right ventricular pacing with mechanical dyssynchrony causes apoptosis interruptus and calcium mishandling. Can J Cardiol 2013;29:510-8.

100. Reddy VY, Neuzil P, Taborsky M, Kralovec S, Sediva L, Ruskin JN. Images in cardiovascular medicine. Electroanatomic mapping of cardiac resynchronization therapy. Circulation 2003;107:2761-3.

101. Akar FG, Nass RD, Hahn S, Cingolani E, Shah M, Hesketh GG et al. Dynamic changes in conduction velocity and gap junction properties during development of pacing-induced heart failure. Am J Physiol Heart Circ Physiol 2007;293:H1223-30.

102. Smith JH, Green CR, Peters NS, Rothery S, Severs NJ. Altered patterns of gap junction distribution in ischemic heart disease. An immunohistochemical study of human myocardium using laser scanning confocal microscopy. Am J Pathol 1991;139:801-21.

103. Josephson ME, Anter E. Substrate mapping for ventricular tachycardia assumptions and misconceptions. JACC Clin Electrophysiol 2015;1:341.

104. Maguy A, Le Bouter S, Comtois P, Chartier D, Villeneuve L, Wakili R et al. Ion channel subunit expression changes in cardiac Purkinje fibers: a potential role in conduction abnormalities associated with congestive heart failure. Circ Res 2009;104:1113-22

105. Valdivia CR, Chu WW, Pu J, Foell JD, Haworth RA, Wolff MR et al. Increased late sodium current in myocytes from a canine heart failure model and from failing human heart. J Mol Cell Cardiol 2005;38:475-83.

106. Kaab S, Nuss HB, Chiamvimonvat N, O'Rourke B, Pak PH, Kass DA et al. lonic mechanism of action potential prolongation in ventricular myocytes from dogs with pacing-induced heart failure. Circ Res 1996;78:262-73.

107. Shvilkin A, Huang HD, Josephson ME. Cardiac memory: diagnostic tool in the making. Circ Arrhythm Electrophysiol 2015;8:475-82.

108. Sosunov EA, Anyukhovsky EP, Rosen MR. Altered ventricular stretch contributes to initiation of cardiac memory. Heart Rhythm 2008;5:106-13.

109. Shvilkin A, Bojovic B, Vajdic B, Gussak I, Zimetbaum P, Josephson ME Vectorcardiographic determinants of cardiac memory during normal ventricular activation and continuous ventricular pacing. Heart Rhythm 2009;6:943-8.

110. Wecke L, Rubulis A, Lundahl G, Rosen MR, Bergfeldt L. Right ventricular pacing-induced electrophysiological remodeling in the human heart and its relationship to cardiac memory. Heart Rhythm 2007;4:1477-86.

111. Wecke L, van Deursen CJ, Bergfeldt L, Prinzen FW. Repolarization changes in patients with heart failure receiving cardiac resynchronization therapy-signs of cardiac memory. J Electrocardiol 2011;44:590-8.

112. Plotnikov AN, Yu H, Geller JC, Gainullin RZ, Chandra P, Patberg KW et al. Role of L-type calcium channels in pacing-induced short-term and long-term cardiac memory in canine heart. Circulation 2003;107:2844-9.

113. Patberg KW, Plotnikov AN, Quamina A, Gainullin RZ, Rybin A, Danilo P, Jr et al. Cardiac memory is associated with decreased levels of the transcriptional factor CREB modulated by angiotensin II and Calcium. Circ Res 2003;93:472-8.

114. Costard-Jäckle A, Goetsch B, Antz M, Franz MR. Slow and long-lasting modulation of myocardial repolarization produced by ectopic activation in isolated rabbit hearts: evidence for cardiac 'memory'. Circulation 1989;80:1412-20.

115. Jeyaraj D, Wilson LD, Zhong J, Flask C, Saffitz JE, Deschênes I et al. Mechanoelectrical feedback as novel mechanism of cardiac electrical remodeling. Circulation 2007;115:3145-55.

116. Opthof T, Janse MJ, Meijborg VM, Cinca J, Rosen MR, Coronel R. Dispersion in ventricular repolarization in the human, canine and porcine heart. Prog Biophys Mol Biol 2016;120:222-35.

117. Shvilkin A, Bojovic B, Vajdic B, Gussak I, Ho KK, Zimetbaum P et al. Vectorcardiographic and electrocardiographic criteria to distinguish new and old left bundle branch block. Heart Rhythm 2010;7:1085-92.

118. Engels EB, Poels TT, Houthuizen P, de Jaegere PP, Maessen JG, Vernooy K et al. Electrical remodelling in patients with iatrogenic left bundle branch block. Europace 2016;18(suppl 4):iv44-52.

119. Maffessanti F, Wanten J, Potse M, Regoli F, Caputo ML, Conte G et al. The relation between local repolarization and T-wave morphology in heart failure patients. Int J Cardiol 2017;241:270-6.

120. Hermeling E, Delhaas T, Prinzen FW, Kuijpers NH. Mechano electrical feedback explains T-wave morphology and optimizes cardiac pump function: insight from a multiscale model. Prog Biophys Mol Biol 2012;110:359-71.

121. Kuijpers NH, Hermeling E, Lumens J, Eikelder HT, Delhaas T, Prinzen FW. Mechano-electrical coupling as framework for understanding functional remodeling during LBBB and CRT. Am J Physiol Heart Circ Physiol 2014;306: H1644-59. 
122. Lieberman R, Padeletti L, Schreuder J, Jackson K, Michelucci A, Colella A et al. Ventricular pacing lead location alters systemic hemodynamics and left ventricular function in patients with and without reduced ejection fraction. I Am Coll Cardiol 2006;48:1634-41.

123. Nahlawi M, Waligora M, Spies SM, Bonow RO, Kadish AH, Goldberger JJ. Left ventricular function during and after right ventricular pacing. I Am Coll Cardiol 2004;44:1883-8.

124. Kass DA, Chen C-H, Curry C, Talbot M, Berger R, Fetics B et al. Improved left ventricular mechanics from acute VDD pacing in patients with dilated cardiomyopathy and ventricular conduction delay. Circulation 1999;99:1567-73.

125. Duckett SG, Ginks M, Shetty AK, Bostock J, Gill JS, Hamid S et al. Invasive acute hemodynamic response to guide left ventricular lead implantation predicts chronic remodeling in patients undergoing cardiac resynchronization therapy. J Am Coll Cardiol 2011;58:1128-36.

126. Delnoy PP, Ottervanger JP, Luttikhuis HO, Nicastia DM, Elvan A, Misier AR et al. Sustained benefit of cardiac resynchronization therapy. J Cardiovasc Electrophysiol 2007;18:298-302.

127. Salameh A, Dhein S, Blanke K, Rastan A, Hiyasat B, Dietze A et al. Right or left ventricular pacing in young minipigs with chronic atrioventricular block: longterm in vivo cardiac performance, morphology, electrophysiology, and cellular biology. Circulation 2012;125:2578-87.

128. Schmidt U, Hajiar RJ, Helm PA, Kim CS, Doye AA, Gwathmey JK. Contribution of abnormal sarcoplasmic reticulum ATPase activity to systolic and diastolic dysfunction in human heart failure. J Mol Cell Cardiol 1998;30:1929-37.

129. lyengar S, Haas G, Lamba S, Orsinelli DA, Babu GJ, Ferketich AK et al. Effect of cardiac resynchronization therapy on myocardial gene expression in patients with nonischemic dilated cardiomyopathy. J Card Fail 2007;13:304-11.

130. Mullens W, Bartunek J, Tang WH, Delrue L, Herbots L, Willems R et al. Early and late effects of cardiac resynchronization therapy on force-frequency relation and contractility regulating gene expression in heart failure patients. Heart Rhythm 2008;5:52-9.
131. Lin JM, Lai LP, Chou NK, Lin JL. Spatial heterogeneity of protein expression induced by dyssynchronous right ventricular pacing in the left ventricle of dogs with preserved systolic function. J Card Fail 2010;16:700-6.

132. Crossman DJ, Jayasinghe ID, Soeller C. Transverse tubule remodelling: a cellular pathology driven by both sides of the plasmalemma? Biophys Rev 2017;9:919-29.

133. Sachse FB, Torres NS, Savio-Galimberti E, Aiba T, Kass DA, Tomaselli GF et al. Subcellular structures and function of myocytes impaired during heart failure are restored by cardiac resynchronization therapy. Circ Res 2012;110:588-97.

134. Li H, Lichter JG, Seidel T, Tomaselli GF, Bridge JH, Sachse FB. Cardiac resynchronization therapy reduces subcellular heterogeneity of ryanodine receptors, T-tubules, and $\mathrm{Ca} 2+$ sparks produced by dyssynchronous heart failure. Circ Heart Fail 2015;8:1105-14.

135. Bhargava V, Shabetai R, Mathiäsen RA, Dalton N, Hunter J], Ross J. Loss of ad renergic control of the force-frequency relation in heart failure secondary to idiopathic or ischemic cardiomyopathy. Am / Cardiol 1998;81:1130-7.

136. Vanderheyden M, Mullens W, Delrue L, Goethals M, Verstreken S, Wijns W et al. Endomyocardial upregulation of beta1 adrenoreceptor gene expression and myocardial contractile reserve following cardiac resynchronization therapy. J Card Fail 2008;14:172-8.

137. Ungerer M, Böhm M, Elce JS, Erdmann E, Lohse MJ. Altered expression of betaadrenergic receptor kinase and beta 1-adrenergic receptors in the failing human heart. Circulation 1993;87:454-63.

138. Chakir K, Depry C, Dimaano VL, Zhu WZ, Vanderheyden M, Bartunek J et al. Galphas-biased beta2-adrenergic receptor signaling from restoring synchronous contraction in the failing heart. Sci Transl Med 2011;3:100ra88.

139. Chakir K, Daya SK, Aiba T, Tunin RS, Dimaano VL, Abraham TP et al. Mechanisms of enhanced beta-adrenergic reserve from cardiac resynchronization therapy. Circulation 2009;119:1231-40.

140. Kirk JA, Holewinski RJ, Kooij V, Agnetti G, Tunin RS, Witayavanitkul N et al. Cardiac resynchronization sensitizes the sarcomere to calcium by reactivating GSK-3beta. J Clin Invest 2014;124:129-38. 